\title{
COLONIZATION OF GROUP B STREPTOCOCCI IN PREGNANT WOMEN AT DELIVERY
}

\author{
Fatma Yilmaz KARADAĞํㅜ, Kenan HIZEL ${ }^{2}$, Orhan GELISEN ${ }^{3}$ \\ 1 Department of Infectious Diseases and Clinical Microbiology, Istanbul University of Medeniyet, Goztepe Research \\ and Training Hospital, Istanbul \\ 2 Department of Clinical Bacteriology and Infectious Diseases, Gazi University, School of Medicine, Ankara \\ 3 Department of Obstetrics and Gynecology, Etlik Zubeyde Hanim Obstetrics \\ and Gynecology Research and Training Hospital, Ankara
}

\begin{abstract}
SUMMARY
Objective: In this study, Group B streptococci (GBS) colonization was evaluated in pregnant women at delivery. Methods: Demographic characteristics and risk factors of 300 pregnant women at delivery at Etlik Zubeyde Hanim Obstetrics and Gynecology Research and Training Hospital were recorded. Rectovaginal swab samples obtained from pregnant women were analysed for GBS using two different methods (CAMP and latex agglutination). Antibiotic sensitivity of the isolated bacteria was determined using disk diffusion method. Statistical evaluations were performed using chi-square tests.

Results: Rectovaginal colonization with GBS was detected in 3\% of cases. No associations observed between GBS colonization and age, occupation, underlying disease, previously used contraception methods, education and income level, and number of previous pregnancies and deliveries. GBS colonization was not associated with preterm birth act or early or prolonged membrane rupture. Antimicrobial resistance rate in isolated GBS was $22 \%$ for clindamycin and erythromycin, and $89 \%$ for tetracycline.

Conclusion: Rate of GBS colonization was low among pregnant women enrolled to our study, therefore it is concluded that routinely intrapartum prophylaxis is not necessary and that national guidelines are required to define prophylaxis conditions.
\end{abstract}

Key words: colonization, group B streptococci, pregnancy

Journal of Turkish Society of Obstetrics and Gynecology, (J Turk Soc Obstet Gynecol), 2013; Vol: 10, Issue: 1, Pages: 16- 20

\section{DOĞUM EYLEMINDEKİ GEBELERDE GRUP B STREPTOKOK KOLONIZASYONU}

\section{ÖZET}

Amaç: Bu çalışmada doğum eylemindeki gebelerde Grup B streptokok (GBS) kolonizasyonu araştırıldı.

Yöntemler: Etlik Zübeyde Hanım Kadın Hastalıkları Ĕ̆itim ve Araştırma Hastanesi'nde doğum eylemindeki 300 gebenin demografik özellikleri ve risk faktörleri kaydedildi. Gebelerden alınan rektovajinal sürüntü örnekleri GBS aç ısından iki farkl yöntemle (CAMP ve lateks aglutinasyon) incelendi. İzole edilen bakterilerin disk difüzyon yöntemi ile antibiyotik duyarlılıkları saptandı. İstatistiksel değerlendirme ki-kare testi ile yapıldı.

Bulgular: Olguların \% 3'ünde GBS ile rektovajinal kolonizasyon saptandı. GBS kolonizasyonuyla yaş, meslek, altta yatan hastalı, önceden gebelikten korunma yöntemi, eğitim ve gelir düzeyi, önceki gebelik ve doğum sayıları arasında bir ilişki gözlenmedi. GBS kolonizasyonunun erken doğum, erken ya da uzamış membran rüptürüyle birlikteliği

Address for Correspondence: Dr. Fatma Yılmaz Karadağ. Atapol Residence, Armağan Evler Mah. Sirt Sok. A 5 Blok Daire: 31 , Ataşehir, İstanbul Phone: +90 (532) 4947329

e-mail: dr_fatma@hotmail.com

Received: 29 December 2011, revised: 27 September 2012, accepted:: 07 October 2012, online publication: 08 October 2012 
gözlenmedi. İzole edilen GBS'lerde klindamisin ve eritromisine \%22, tetrasikline \%89 direnç saptandl.

Sonuç: Çalışmaya aldığımız gebelerde GBS kolonizasyonu düş̧ük oranda saptanmış olup rutin intrapartum profilaksinin gerekmediği ve profilaksi uygulama koșullarını belirleyen ulusal boyuttaki kılavuzların hazırlanmasının uygun olacăğ sonucuna ulaşılmıștır.

Anahtar kelimeler: gebelik, kolonizasyon, grup B streptokok

Türk Jinekoloji ve Obstetrik Derneği Dergisi, (J Turk Soc Obstet Gynecol), 2013; Cilt: 10, Sayl: 1, Sayfa: 16-20

\section{INTRODUCTION}

Group B streptococci (GBS, Streptococcus agalactiae) were recognized as significant agent of mastitis in cows until 1938. On the other hand few sporadic human cases were reported until 1970, and then both early and late onset newborn infections due to GBS were started to be reported $(1,2)$.

Natural localizations of GBS in human are lower gastrointestinal system, pharyngeal and vaginal flora and they most frequently invade genitourinary system $^{(1,3)}$. Vaginal and cervical colonization with GBS leads to development of infections in varying severity both in mother and newborn ${ }^{(4,5)}$.

This bacteria is transmitted to newborn via vertical or horizontal way from pregnant women with anorectal carriage. Two different clinical pictures are seen in newborn: early and late onset ${ }^{(1,4)}$. Infections with early onset are appeared within first seven days and more frequently within first 24 hours following delivery. Most frequently serious clinical conditions such as sepsis, pneumonia and meningitis are observed. Although difference is present between countries, incidence of infection with early onset varies between 0.7 and 3.7 per 1000 live births ${ }^{(1,4,6)}$. Infections with late onset are appeared within 8 days to 3 months following delivery. During this period, clinical conditions such as meningitis, osteomyelitis, septic arthritis and cellulitis are observed. Incidence of infection with late onset varies between 0.3 and 1.8 per 1000 live births ${ }^{(1,4)}$.

Although GBS infection may be asymptomatic in pregnant women, it may be appeared as asymptomatic bacteriuria, cystitis, pyelonephritis, endometritis, wound infection after cesarean section or episiotomy, puerperal sepsis, meningitis and thrombophlebitis with serious complications such as preterm birth act, early membrane rupture (EMR), prolonged membrane rupture (PMR) and chorioamnionitis $^{(7)}$. Since it may cause serious infections, it is necessary to define basic strategies to prevent and treat GBS infections. Previous studies demonstrate substantial decrease in rate of newborn infections by intrapartum prophylaxis ${ }^{(8)}$. However, proportion of newborn infections due to GBS is not clear yet in Turkey. Therefore GBS colonization rate in pregnancy should be firstly determined. In this study, frequency of GBS in pregnant women at delivery was analyzed.

\section{MATERIALS AND METHOD}

Three hundred pregnant women at delivery presented to the Etlik Zubeyde Hanim Obstetrics and Gynecology Research and Training Hospital were included in this study. Pregnant women were questioned about possible risk factors such as age, occupation, education and income level, underlying diseases, number of previous pregnancy and delivery, history of febrile illnesses during puerperal period and in infants during first three months, and method of contraception used during last six months prior to pregnancy. Week of pregnancy was recorded and presence of preterm birth act, EMR and PMR was evaluated.

Sterile swab samples from the lower $1 / 3$ vagina and rectum of pregnant women included in the study were obtained. Samples were inoculated into selective ToddHewitt liquid medium containing nalidixic acid $15 \mu \mathrm{g} / \mathrm{ml}$ and gentamicin sulphate $8 \mu \mathrm{g} / \mathrm{ml}$ at $37^{\circ} \mathrm{C}$ and they are incubated for 18 to 24 hours under aerobic conditions. Following incubation, passage from liquid broth to sheep blood 5\% agar, was done. Samples passaged to blood agar were stored at $37^{0} \mathrm{C}$ for 24 to 48 hours. Catalase test followed by Gram staining and bacitracin test were done for colonies with compatible morphology with GBS and surrounding narrow beta hemolysis. Catalase negative and bacitracin resistant colonies with chain formation and gram positive cocci appearance were examined by CAMP and Latex agglutination (Slidex Strepto B-Biomerieux) tests. Microorganisms with positive results in both tests were identified as GBS. 
Isolated GBS strains were confirmed by BBL Crystal Gram Positive (Becton Dickinson, USA) identification kit and antibiotic sensitivity was determined by disk diffusion method. Statistical evaluation of risk factors for cases with GBS positive was performed using chisquare tests in a computer program (EPI-INFO 2000).

\section{RESULTS}

Pregnant women included in the study were between 16 and 41 years of age and mean age was 25 years (4.6 (median:24 years)). Pregnancy week was between 22 and 44 weeks, mean was 38.2 weeks (3.2 (median 39.0 weeks)). Among vaginal and rectal samples simultaneously taken from pregnant women, GBS was isolated from only 9 of vaginal culture samples (3\%).

Thirteen pregnant women used previously antibiotics due to urinary infection, however, antibiotics could not be determined. GBS was not the etiologic agent in any of pregnant women with history of urinary infection. None of the pregnant women had malignancy, immunosuppressive disease or history of immunosuppressive drugs administration, hypertension, and chronic diseases of lungs, heart, liver or kidney. Although GBS was detected in two of 17 pregnant women with diabetes, no statistical association between diabetes and GBS positivity was detected ( $\mathrm{p}>0.05)$. Education and income level did not affect frequency of GBS. There was no relationship between methods of contraception prior to pregnancy and GBS colonization ( $\mathrm{p}>0.05$ ). GBS isolation in housewives was not statistically higher compared to working women ( $\mathrm{p}>0.05$ ).

Age distribution of pregnant women is shown in Table I with no statistical difference between age and GBS isolation. Similarly, number of previous delivery had no effect on GBS proliferation.

Table I: Frequency of detection of GBS in different age groups in pregnant women

\begin{tabular}{lll}
\hline \multirow{2}{*}{ Age Group (years) } & \multicolumn{2}{c}{ GBS proliferation (\%) } \\
\cline { 2 - 3 } & Positive & Negative \\
\hline $16-20$ & - & $45(100)$ \\
$21-25$ & $8(6.0)$ & $126(94.0)$ \\
$26-30$ & - & $82(100)$ \\
$31-35$ & $1(3.1)$ & $31(96.9)$ \\
36 ve üstü & - & $7 \quad(100)$ \\
Toplam & $\mathbf{9 ( 3 . 0 )}$ & $\mathbf{2 9 1}(\mathbf{9 7 . 0 )}$ \\
\hline $\mathrm{p}=0.08$ & &
\end{tabular}

J Turk Soc Obstet Gynecol 2013; 10: 16- 20
There was no significant difference between pregnant women with at least one of the risk factors such as EMR, PMR and preterm birth act with higher probability of Group B streptococci infections and pregnant women with no risk factors in terms of GBs isolation.

Antimicrobial resistance rate in isolated GBS was $22 \%$ for clindamycin and erythromycin, and $89 \%$ for tetracycline, but no resistance wes detected for penicilline $\mathrm{G}$, ampicilline, meropenem and vancomycine.

\section{DISCUSSION}

GBS colonization rate varies from $15 \%$ to $40 \%$ among different contries and it becomes increasingly a health problem $^{(4.5)}$. Reason for this discrepancy between countries originates from the fact that GBS colonization varies according to the geographical area, ethnic origin and methods of intrapartum contraception ${ }^{(8,9)}$. In USA, incidence of newborn infections due to GBS is 1 to 4 per 1000 live births, while this figure is 0 to 3 in UK $(2,6)$. GBS colonization rate is $11.4 \%$ and $24.9 \%$ in USA, $12 \%$ and $15 \%$ in Europe, $21.5 \%$ in Middle East and $11.4 \%$ and $27.9 \%$ in $\operatorname{Japan}^{(6,10)}$. Frequency of GBS in Turkey has been determined as between $1 \%$ and $16 \%$ in different studies ${ }^{(11-20)}$. When all previous studies are considered, GBS frequency in Turkey is lower than some other countries. One reason may be less occurrence of GBS colonization in Caucasian compared to blacks or Hispanics( ${ }^{(1)}$. Different rates in Turkey found in different studies were attributed to differences in regional difference in addition to lack of a standardized method used in detection of the colonization. In our study, GBS colonization rate in pregnant women was found to be $3 \%$, consistent with other studies using similar methods.

In majority of previous studies, higher rate of GBS colonization has been reported in individuals giving childbirth at ages younger than 20 years and having three or less deliveries(21). In USA, where GBS infections constitute a major health problem, risk of GBS colonization was reported to be decreased with increasing number of childbirth but increased with increased age of pregnant woman ${ }^{(10)}$. On the contrary, in a Turkish study, rate of GBS colonization was found to be increased with increased age and number of pregnancy ${ }^{(11)}$. In certain other studies like ours, no 
effect of age and number of childbirth was found on GBS colonization ${ }^{(22,23)}$.

Certain studies reported that use of intrauterine devices (IUD) caused to vaginal GBS colonization although the reasons were not completely understood ${ }^{(22)}$. Regan et al. on the other hand, reported no effect of method of contraception on colonization ${ }^{(10,24)}$. In our study, no significant associations were found between method of contraception and GBS colonization; however, low rate $(4 \%)$ of pregnant women using IUD in the last 6 months prior to pregnancy limited statistical evaluation.

GBS was isolated in $13.6 \%$ in the microbiological evaluations of vaginal samples of healthy pregnant women $^{(25)}$. GBS colonized in pregnant woman may cause preterm birth act, EMR and $\operatorname{PMR}^{(26)}$. However, in certain studies, it is reported that risk of development of EMR and PMR are not increased by GBS colonization ${ }^{(7,27)}$. In our study no significant association was detected between GBS colonization and EMR and PMR.

Another controversial subject is the question of whether lower socioeconomic level and low education level increase GBS colonization(10,23). In our study, GBS colonization rate was not increased in pregnant women with lower socioeconomic and education levels. Similarly, no significant associations between being a housewife and GBS colonization was found, consistently with others reported in the literature ${ }^{(10)}$.

Intrapartum prophylaxis is recommended in pregnant women with risk factors (preterm birth act, EMR, $\mathrm{PMR}$, fever $>38^{\circ} \mathrm{C}$ at delivery, urinary infection due to GBS during pregnancy, and history of GBS related disease in children of pregnant woman) or in women with positive rectovaginal GBS cultures obtained between weeks 35 and 37 of pregnancy in order to prevent perinatal GBS infections $(6,8,20)$. However, progressively increasing rate of resistance to antibiotics used in intrapartum prophylaxis has become an important issue. Although no resistance was reported for penicillin, ampicillin, cefazoline and vancomycin in GBS, incidence of resistance for clindamycin and erythromycin was $3-21 \%$ and $5-29 \%$, respectively $(28,29)$. Reports of antibiotic sensitivity in GBS from Turkey is limited; no resistance for clindamycin was identified in two different studies, while resistance for erythromycin was not evaluated ${ }^{(12,13)}$. In our study resistance was $89 \%$ for tetracycline and $22 \%$ for erythromycin and clindamycin and these are conforme with the international studies.

Rate of newborn infections due to Group B streptococci is progressively decreasing in USA. Main reason of reduction is preperation of nationwide guidelines and their effective application. However, it is important to avoid unnecessary use of antibiotics in pregnant women in order to prevent antibiotic resistance of microorganisms, to decrease concerns of pregnant women about antibiotic use, and to decrease costs. This fact is especially important in countries like ours where the incidence of GBS is low. In conclusion, each country should identify its own prevalance of GBS infections and thus prepare its own guidelines to determine conditions requiring prophylaxis against GBS infections.

\section{REFERENCES}

1. Baker CJ. Group B streptococcal infections. In Kaplan EL Stevens DL, Eds. Streptococcal infections. 3rd ed. New York: Oxford University Pres, 2000: 22- 237.

2. Rausch AV,Gross A, Droz S, Bodmer T, Surbek DV. Group B streptococcus colonization in pregnancy: prevalence and prevention strategies of neonatal sepsis. J Perinat Med 2009; 37(2): 124- 9.

3. Schrag S, Gorwitz R, Fultz-Butts K, Schuchat A. Prevention of perinatal group B streptococcal disease. Revised guidelines from CDC. MMWR 2002; 51(RR-11): 1- 22.

4. Remington JS, Klein OJ. Group B streptococcal infections. In Edwards SM, Baker JC, eds. Infectious diseases of the fetus and newborn infant. 5th ed. Philadelphia: WB Saunders, 2001; 1092- 140 .

5. Nandyal RR. Update on Group B streptococcal infections: perinatal and neonatal periods. J Perinat Neonatal Nurs 2008; 22(3): $230-7$.

6. Sidky I,Thomas M. Prevalence of group B streptococcal infection colonisation in pregnant women and their offspring in The Middle East. J Obstet Gynaecol 2002; 22(2): 179- 80.

7. Matorras R, Garcia Perea A, Omenaca F, Usandizaga JA, Nieto A, Herruzo R. Group B streptococcus and premature rupture of membranes and preterm delivery. Gynecol Obstet Invest 1989; 27(1): 14- 8.

8. Schrag SJ, Zywicki S, Farley MM, et al. Group B streptococcal disease in the era of intrapartum antibiotic prophylaxis. $\mathrm{N}$ Engl J Med 2000; 342(1): 15- 20.

9. Hager WD, Schuchat A, Gibbs R, Sweet R, Mead P, Larsen 
JW. Prevention of perinatal group B streptococcal infection: Current controversies. Obstet Gynecol 2000; 96(1): 141- 5 .

10. Regan JA, Klebanoff MA, Nugent RP. The epidemiology of group B streptococcal colonization in pregnancy. Obstet Gynecol 1991; 77(4): 604- 10.

11. Arısoy AS, Kurutepe S, Algün Ü, Çelik H, İspahi Ç, Özbakkaloğlu B. Üçüncü trimestr gebelerde grup B streptokok kolonizasyonu. İnfeksiyon Dergisi 2000; 14(1): 57- 9.

12. Çelebi S, Tuncel E, Babacan M. Yöremizde gebe kadınlar ve yenidoğanlarda B grubu streptokok prevalansı. Mikrobiyol Bült 1992; 26(2): 149- 54.

13. Gökalp A, Oğuz A, Bakıcı Z, et al. Neonatal grup B streptokok kolonizasyonunun annelerdeki ve anorektal sistem taşıyıcılığ ile ilişkisi. Mikrobiyol Bült 1986; 20: 248- 55.

14. Karaeminoğulları M, Memiş S. Üçüncü trimestr gebelerde hızlı tarama testi ile grup B streptokok kolonizasyonunun saptanması. Klimik Derg 1992; 5(2): 35- 6.

15. Polat E, Özer Y, Çepni I, et al. Gebe kadınlarda grup B streptokok kolonizasyonu. Klimik Derg 2003; 16(Suppl): 304.

16. Yavuz MT, Akçay T, Güdükcüoğlu H, Berktaş M, Yavuz Ö, Bozkurt H. Gebe kadınların alt genital organ ve rektumlarında B grubu streptokokların görülme sıklığının araştırılması [Özet]. In: Tekeli E, Willke A, eds. 8. Türk Klinik Mikrobiyoloji ve İfeksiyon Hastalıkları Kongresi, Kongre Program ve Özet Kitabı. İstanbul: Klinik Mikrobiyoloji ve İnfeksiyon Hastalıkları Derneği \& Türk Mikrobiyoloji Cemiyeti, 1997: 356.

17. Gül HC, Dede M, Avcı IY, Eyigün CP, Pahsa A. Üçüncü Trimestr Hamilelerde Vaginal Grup B Streptokok Kolonizasyonu. Klimik Dergisi 2005; 18(1): 27 - 9.

18. Karakuş M, Karaca Demirci Y, Günçiner Ş. Gebelerde grup B streptokok kolonizasyonu ve antimikrobiyal direnç paterni. Ege Tip Dergisi 2007; 46(3): 151- 4

19. Ilıkhan B, Carıkcı M, Vural M, et al. The colonization incidence of group B streptococcus in pregnant women and their newborns in İstanbul. Pediatrics International 2005; 47(1): 64- 6.
20. Yücesoy G, Calışkan E, Karadenizli A, et al. Maternal colonization with group B streptococcus and effectiveness of a culture-based protocol to prevent early-onset neonatal sepsis. Int J Clin Pract 2004; 58(8): 735- 9.

21. Karakoç AE, Acar N. Grup B streptokoklar. İnfeksiyon Hastalıkları Dergisi 2002; 5: 68- 76

22. Farrag OA, Gawad AA, Antar S. Group B-beta haemolytic streptococcal colonization in women using intrauterine contraceptive devices. Contraception 1985; 31(6): 595- 602.

23. Feikin DR, Thorsen P, Zywicki S, Arpi M, Westergaard JG, Schuchat A. Association between colonization with group B streptococci during pregnancy and preterm delivery among Danish women. Am J Obstet Gynecol 2001; 184(3): 427- 33.

24. Eren A, Küçükercan M, Oğuzoğlu N, Ünal N, Karateke A. The carriage of group B streptococci in Turkish pregnant women and its transmission rate in newborns and serotype distribution. Turk J Pediatr 2005; 47(1): 28- 33.

25. Shokouhizadeh S, Köksal F, Yarkın F, et al. Gebe kadınların genitoüriner sistemlerinde Mycoplasma ve B grubu streptokokların insidansı ile gebeliğe etkileri. Mikrobiyol Bült 1992; 26(3): 253- 60 .

26. McGregor JA, French JI, Seo K. Premature rupture of membranes and bacterial vaginosis. Am J Obstet Gynecol 1993; 169(2 Pt 2): 463- 6

27. Kubota T. Relationship between maternal group B streptococcal colonization and pregnancy outcome. Obstet Gynecol 1998; 92(6): 926- 30

28. Manning SD, Foxman B, Pierson CL, Tallman P, Baker CJ, Pearlman MD. Correlates of antibiotics-resistant group B streptococcus isolated from pregnant women. Obstet Gynecol 2003; 101(1): 74- 9

29. Spaetgens R, DeBella K, Ma D, Robertson S, Mucenski M, Davies HD. Perinatal antibiotic usage and changes in colonization and resistance rates of group B streptococcus and other pathogens. Obstet Gynecol 2002; 100(3): 525- 33. 